\title{
Technologically significant properties of municipal solid waste compost
}

\author{
Grigorii Kozlov ${ }^{1}$, Mikhail Pushkarev ${ }^{1, *}$, Dmitry Danilovich ${ }^{1}$, and Alexander Garabadzhiu ${ }^{1}$ \\ ${ }^{1}$ Saint-Petersburg State Institute of Technology, 190013, 26 Moskovsky prospect, St. Petersburg, \\ Russia
}

\begin{abstract}
The paper presents the results of studies of the technologically significant properties of municipal solid waste (MSW) compost produced by MSW processing enterprises in St. Petersburg (Russia) where the Dano drum process is implemented. The chemical and microbiological composition of compost, as well as heat during ripening, are investigated. The chemical composition of industrial compost produced in St. Petersburg does not make it possible to use it as fertilizers and soil in agriculture. From the microbiological point of view, NSW compost is not dangerous, but the content of indicator groups of microorganisms classifies it as contaminated soil. The heat generation of compost during ripening is uneven - the largest share of heat $78.5 \%$ is released in the first year of maturation. In absolute terms, this value is $3250 \mathrm{~kJ} / \mathrm{kg}$ by dry weight. To ensure the process is carried out during a period when the compost temperature is higher than the ambient temperature, toxic substances must be added to the compost in an amount not more than 400 times the pollutant content in waste of the 4 th hazard class.
\end{abstract}

\section{Introduction}

One of the most important classes of pollutants is polycyclic aromatic hydrocarbons (PAHs). The carcinogenicity of a large number of substances of this class, as well as a large amount of emission, make PAHs a priority object for environmental research and the development of technologies for their biodegradation.

Composting with various organic wastes as a way to neutralize PAHs is widely known. This approach was simulated for composts from silt sediments of sewage [1] soils contaminated with creosote [2] wood of railway sleepers (together with waste from poultry farms and plant biomass) [3]. The degradation of PAHs by thermophiles was shown [4], however, after optimizing the process of biodegradation of PAHs in compost, it was found that a temperature $38^{\circ} \mathrm{C}$ provides more effective biodegradation than $55^{\circ} \mathrm{C}$ or $70{ }^{\circ} \mathrm{C}$ [5].

During the process of preparation and maturation, waste compost goes through all temperature ranges, and its microbiological composition changes, which makes waste compost an ideal environment for the destruction of complex mixtures of toxic substances (which are chemical waste), since the spectrum of substances destroyed by PAH destructors of different taxa can vary quite significantly, which is given in the reviews $[6,7]$, the list of

\footnotetext{
${ }^{*}$ Corresponding author: malexpush@bk.ru
} 
PAH destructors updated for wood of railway sleepers is given in [8]. A comparison of literature data with the results of microbiological analysis [9] suggests that microorganisms described as PAH destructors are present in MSW compost. We have shown in previous work [10] the destruction of PAHs in municipal solid waste (MSW) compost. In this regard, it seems relevant to study in detail the technologically important properties of MSW - compost (heat, chemical composition, microbiological composition by months of the year), with the aim of improving the technology for the disposal of PAHs containing waste.

\section{Materials and methods}

Compost samples were obtained at the production site of Experimental Plant for the Mechanized Processing of Household Waste (branch of St. Petersburg State Unitary Enterprise "Plant for the Mechanized Processing of Household Waste") located in the Gorelovo village.

Quantitative microbiological analysis and study of the properties of cultures was carried out using classical microbiological culture media, dyes, and methods [11, 12].

The thermal effects of composting processes were determined by comparing the initial and final calorific values of composts. The studies were conducted on Shimadzu DSC-60 Plus differential scanning calorimeter at the Engineering Center of Saint-Petersburg State Institute of Technology. The determination of thermal effects was carried out for samples weighing $0.020 \mathrm{~g}$ in a stream of air. Compost samples were dried in air at room temperature and grounded in a porcelain mortar.

PAHs were determined by chromatography-mass spectrometry on a QP-5000 Shimadzu chromatograph. The internal standard is 2-fluoronaphthalene. Calibration mixture "Supelso - 8270/625 / CLP Semivolatile Calib. Mix." .

The chemical properties of compost were determined in the laboratory of the Center for Hygiene and Epidemiology in the city of St. Petersburg: total nitrogen (GOST 26715-85); total phosphorus, potassium and arsenic (according to Guidelines for Sanitary Chemical Investigation of Soil); mobile calcium (GOST 26487-85); nitrate nitrogen (GOST 2695186); total copper, zinc, cadmium, lead, nickel (according to Guidance Document 52.18.19189); total cobalt (ISO 11047:1997); total mercury (according to Federal Regulations $16.1: 2.3: 3.10-98)$.

\section{Results and discussions}

\subsection{The chemical composition of compost}

Five samples of composts from various batches obtained at the production site of Experimental Plant for the Mechanized Processing of Household Waste were analyzed. The main agrochemical indicators and the content of heavy metals were determined, the results are shown in Table 1.

The content of nitrate nitrogen varies greatly, which is associated with the different quality of food products that have become food waste - the content of nitrates in them is very different. Other agrochemical characteristics, namely the content of nitrogen, phosphorus and potassium, mobile calcium are comparable for different batches. The same should be said for the content of mercury, arsenic, cobalt, cadmium and copper. This is due to the fact that the elemental composition of the composted part by biogenic elements is stable, as well as the fact that the pollution with the metals mentioned above is stable and it will be difficult to reduce it by sorting, because for example mercury lamps are collected separately. At the same time, the content of zinc, lead, chromium and nickel varies very 
much, which is associated with different contents of batteries in MSW from different areas of the city, so the content of these metals can be drastically reduced due to the selective collection of batteries. In general, as expected, the high content of heavy metals in the compost makes it unsuitable for use in the form of fertilizer/soil (with the exception of landfill reclamation) or biofuel for greenhouses.

Table 1. The chemical composition of MSW compost.

\begin{tabular}{|c|c|c|c|c|c|c|}
\hline \multirow{2}{*}{$\begin{array}{c}\text { Indicator, } \\
\text { units measuring }\end{array}$} & \multicolumn{7}{|c|}{ Compost sample } & \multirow{2}{*}{ Error, \% } \\
\cline { 2 - 6 } & 1 & 2 & 3 & 4 & 5 & 0.1 \\
\hline Total $\mathrm{N}, \%$ & 0.97 & 1.1 & 1.02 & 0.90 & 0.95 & 30 \\
\hline Total $\mathrm{P}, \%$ & 0.48 & 0.52 & 0.50 & 0.53 & 0.47 & 25 \\
\hline Total $\mathrm{K}, \%$ & 0.30 & 0.36 & 0.39 & 0.35 & 0.44 & 17 \\
\hline Mobile $\mathrm{Ca}, \%$ & 2.1 & 1.7 & 2.0 & 2.0 & 2.1 & 20 \\
\hline Nitrate $\mathrm{N}, \mathrm{mg} / \mathrm{kg}$ & 184.1 & 96.6 & 140.0 & 430.3 & 149.6 & 15 \\
\hline Total $\mathrm{Cu}, \mathrm{mg} / \mathrm{kg}$ & 65.0 & 66.9 & 51.4 & 39.7 & 63.1 & 20 \\
\hline Total $\mathrm{Zn}, \mathrm{mg} / \mathrm{kg}$ & 567.3 & 643.7 & 477.3 & 370.7 & 583.9 & 25 \\
\hline Total $\mathrm{Co}, \mathrm{mg} / \mathrm{kg}$ & 5.3 & 4.6 & 2.0 & 3.7 & 1.7 & 35 \\
\hline Total $\mathrm{Cd}, \mathrm{mg} / \mathrm{kg}$ & 2.8 & 2.1 & 1.4 & 1.5 & 1.3 & 15 \\
\hline Total $\mathrm{Pb}, \mathrm{mg} / \mathrm{kg}$ & 663.5 & 398.2 & 277.6 & 92.8 & 497.3 & 20 \\
\hline Total $\mathrm{Cr}, \mathrm{mg} / \mathrm{kg}$ & 98.1 & 43.3 & 25.7 & 31.7 & 19.7 & 15 \\
\hline Total $\mathrm{Ni}, \mathrm{mg} / \mathrm{kg}$ & 7.6 & 77.4 & 22.9 & 10.2 & 35.6 & 30 \\
\hline Total $\mathrm{As}, \mathrm{mg} / \mathrm{kg}$ & 3.5 & 3.0 & 2.3 & 1.8 & 2.7 & 25 \\
\hline Total $\mathrm{Hg}, \mathrm{mg} / \mathrm{kg}$ & 0.29 & 0.23 & 0.24 & 0.28 & 0.19 & \\
\hline
\end{tabular}

\subsection{The microbiological composition of compost during ripening}

The key factor affecting the composition of the compost microflora is the temperature, which is the result of the influence of the ambient temperature, and on the other hand, the compost's own heat release. A study was made of the microbiological composition of compost of different ripening periods (from fresh to 5 years of storage) for the months of the year, the results of which are presented in tables 2-5.

Table 2. Total microbial count (bacteria), $\mathrm{CFU} /(\mathrm{g}$ of dry sample).

\begin{tabular}{|c|c|c|c|c|}
\hline \multirow{2}{*}{ Period } & \multicolumn{4}{|c|}{ Compost ripening period } \\
\cline { 2 - 5 } & Fresh & 1 year & $2-3$ years & 5 years \\
\hline January & $8.5 \cdot 10^{9}$ & $5.0 \cdot 10^{8}$ & $2.8 \cdot 10^{7}$ & No data \\
\hline February & $3.2 \cdot 10^{9}$ & $4.0 \cdot 10^{8}$ & $3.0 \cdot 10^{7}$ & No data \\
\hline March & $1.5 \cdot 10^{9}$ & $2.4 \cdot 10^{8}$ & $6.1 \cdot 10^{7}$ & $1.9 \cdot 10^{8}$ \\
\hline April & $5.5 \cdot 10^{9}$ & $1.5 \cdot 10^{8}$ & $4.3 \cdot 10^{8}$ & $1.2 \cdot 10^{7}$ \\
\hline May & $2.1 \cdot 10^{9}$ & $3.3 \cdot 10^{8}$ & $1.8 \cdot 10^{8}$ & $5.9 \cdot 10^{7}$ \\
\hline June & $8.0 \cdot 10^{9}$ & $7.2 \cdot 10^{8}$ & $2.5 \cdot 10^{8}$ & $4.6 \cdot 10^{8}$ \\
\hline July & $3.2 \cdot 10^{10}$ & $1.5 \cdot 10^{10}$ & $8.1 \cdot 10^{9}$ & $7.3 \cdot 10^{9}$ \\
\hline August & $6.1 \cdot 10^{10}$ & $2.0 \cdot 10^{10}$ & $9.0 \cdot 10^{9}$ & $8.2 \cdot 10^{9}$ \\
\hline September & $4.5 \cdot 10^{9}$ & $3.0 \cdot 10^{9}$ & $5.5 \cdot 10^{8}$ & $2.0 \bullet 10^{8}$ \\
\hline October & $1.5 \cdot 10^{9}$ & $1.6 \cdot 10^{9}$ & $1.0 \cdot 10^{8}$ & $5.0 \cdot 10^{8}$ \\
\hline November & $2.1 \cdot 10^{9}$ & $3.5 \cdot 10^{9}$ & $1.0 \cdot 10^{9}$ & $7.2 \cdot 10^{8}$ \\
\hline December & $4.3 \cdot 10^{9}$ & $6.4 \cdot 10^{8}$ & $3.5 \cdot 10^{7}$ & No data \\
\hline
\end{tabular}


Table 3. Total microbial count (Micromycetes), CFU/(g of dry sample).

\begin{tabular}{|c|c|c|c|c|}
\hline \multirow{2}{*}{ Period } & \multicolumn{4}{|c|}{ Compost ripening period } \\
\cline { 2 - 5 } & Fresh & 1 year & $2-3$ years & 5 years \\
\hline January & $3.8 \cdot 10^{4}$ & $1.6 \cdot 10^{3}$ & $<10^{3}$ & No data \\
\hline February & $1.1 \cdot 10^{4}$ & $1.0 \cdot 10^{3}$ & $<10^{3}$ & No data \\
\hline March & $3.0 \cdot 10^{4}$ & $2.1 \cdot 10^{4}$ & $3.1 \cdot 10^{3}$ & $1.0 \cdot 10^{4}$ \\
\hline April & $2.2 \cdot 10^{5}$ & $5.2 \cdot 10^{5}$ & $4.2 \cdot 10^{4}$ & $1.0 \cdot 10^{4}$ \\
\hline May & $2.0 \cdot 10^{4}$ & $2.5 \cdot 10^{3}$ & $1.1 \cdot 10^{4}$ & $1.0 \cdot 10^{3}$ \\
\hline June & $1.3 \cdot 10^{5}$ & $1.6 \cdot 10^{4}$ & $6.0 \cdot 10^{3}$ & $3.0 \cdot 10^{3}$ \\
\hline July & $1.5 \cdot 10^{4}$ & $1.0 \cdot 10^{3}$ & $6.0 \cdot 10^{3}$ & $2.5 \cdot 10^{3}$ \\
\hline August & $2.2 \cdot 10^{5}$ & $5.6 \cdot 10^{3}$ & $1.4 \cdot 10^{4}$ & $1.0 \cdot 10^{3}$ \\
\hline September & $2.5 \cdot 10^{5}$ & $1.0 \cdot 10^{4}$ & $3.0 \cdot 10^{3}$ & $1.0 \cdot 10^{3}$ \\
\hline October & $2.1 \cdot 10^{6}$ & $4.5 \cdot 10^{4}$ & $7.0 \cdot 10^{3}$ & $<10^{3}$ \\
\hline November & $4.0 \cdot 10^{5}$ & $4.6 \cdot 10^{3}$ & $1.0 \cdot 10^{3}$ & $2.5 \cdot 10^{3}$ \\
\hline December & $1.2 \cdot 10^{4}$ & $1.7 \cdot 10^{3}$ & $<10^{3}$ & No data \\
\hline
\end{tabular}

Table 4. Conditional pathogens (determined dilution, in which the object of analysis is detected).

\begin{tabular}{|c|c|c|c|c|}
\hline \multirow{2}{*}{ Period } & \multicolumn{4}{|c|}{ Compost ripening period } \\
\cline { 2 - 5 } & Fresh & 1 year & $2-3$ years & 5 years \\
\hline January & $10^{6}$ & $10^{5}$ & $10^{4}$ & No data \\
\hline February & $10^{6}$ & $10^{5}$ & $10^{4}$ & No data \\
\hline March & $10^{6}$ & $10^{5}$ & $10^{4}$ & $10^{4}$ \\
\hline April & $10^{5}$ & $10^{5}$ & $10^{4}$ & $10^{4}$ \\
\hline May & $10^{5}$ & $10^{5}$ & $10^{4}$ & $10^{4}$ \\
\hline June & $10^{5}$ & $10^{5}$ & $10^{4}$ & $10^{5}$ \\
\hline July & $10^{5}$ & $10^{4}$ & $10^{5}$ & $10^{4}$ \\
\hline August & $10^{5}$ & $10^{3}$ & $10^{4}$ & $10^{4}$ \\
\hline September & $10^{5}$ & $10^{5}$ & $10^{4}$ & $10^{4}$ \\
\hline October & $10^{5}$ & $10^{5}$ & $10^{4}$ & $10^{5}$ \\
\hline November & $10^{6}$ & $10^{5}$ & $10^{5}$ & No data \\
\hline December & $10^{6}$ & $10^{5}$ & $10^{4}$ & \\
\hline
\end{tabular}

Table 5. Enterobacteria (determined dilution, in which the object of analysis is detected).

\begin{tabular}{|c|c|c|c|c|}
\hline \multirow{2}{*}{ Period } & \multicolumn{4}{|c|}{ Compost ripening period } \\
\cline { 2 - 5 } & Fresh & 1 year & $2-3$ years & 5 years \\
\hline January & $10^{3}$ & $<10^{3}$ & $<10^{3}$ & No data \\
\hline February & $10^{3}$ & $<10^{3}$ & $<10^{3}$ & No data \\
\hline March & $10^{3}$ & $10^{3}$ & $<10^{3}$ & $10^{3}$ \\
\hline April & $10^{4}$ & $10^{3}$ & $10^{3}$ & $10^{3}$ \\
\hline May & $10^{5}$ & $10^{5}$ & $10^{4}$ & $10^{5}$ \\
\hline June & $10^{6}$ & $10^{6}$ & $10^{6}$ & $10^{6}$ \\
\hline July & $10^{6}$ & $10^{6}$ & $10^{6}$ & $10^{6}$ \\
\hline August & $10^{6}$ & $10^{6}$ & $10^{6}$ & $10^{5}$ \\
\hline September & $10^{5}$ & $10^{5}$ & $10^{5}$ & $10^{5}$ \\
\hline October & $10^{5}$ & $10^{5}$ & $10^{5}$ & $10^{5}$ \\
\hline November & $10^{6}$ & $10^{5}$ & $10^{5}$ & No data \\
\hline December & $10^{3}$ & $<10^{3}$ & $<10^{3}$ & \\
\hline
\end{tabular}

From the data obtained, it can be concluded that the microbiological composition of the compost at the exit of the bio-drum and during the ripening period does not depend on the time of year (air temperature), since the temperature $50-60{ }^{\circ} \mathrm{C}$ is maintained in the ripening compost. 
In compost aged 2-3 years, the decomposition of organic substances has already been completed, so the ambient temperature affects the microbial number.

From the data obtained it follows that sanitary indicators of compost from MSW do not cause concern and correspond to the soil of contaminated places, which also limits its use as fertilizers and soil for agriculture.

\subsection{The change in the calorific value of compost during ripening}

The amount of heat generated by compost at different ripening intervals was measured using the Hess law of thermochemistry - since the thermal effect of the reaction does not depend on the reaction path, but only on the initial and final state of substances, the thermal effects of compost were studied using differential scanning calorimetry, the results of which are presented in figures 1-6.

The data indicate that the main amount of heat $3250 \mathrm{~kJ} / \mathrm{kg}(78.5 \%$ of the total heat released during the compost ripening) is released during the first year of composting.

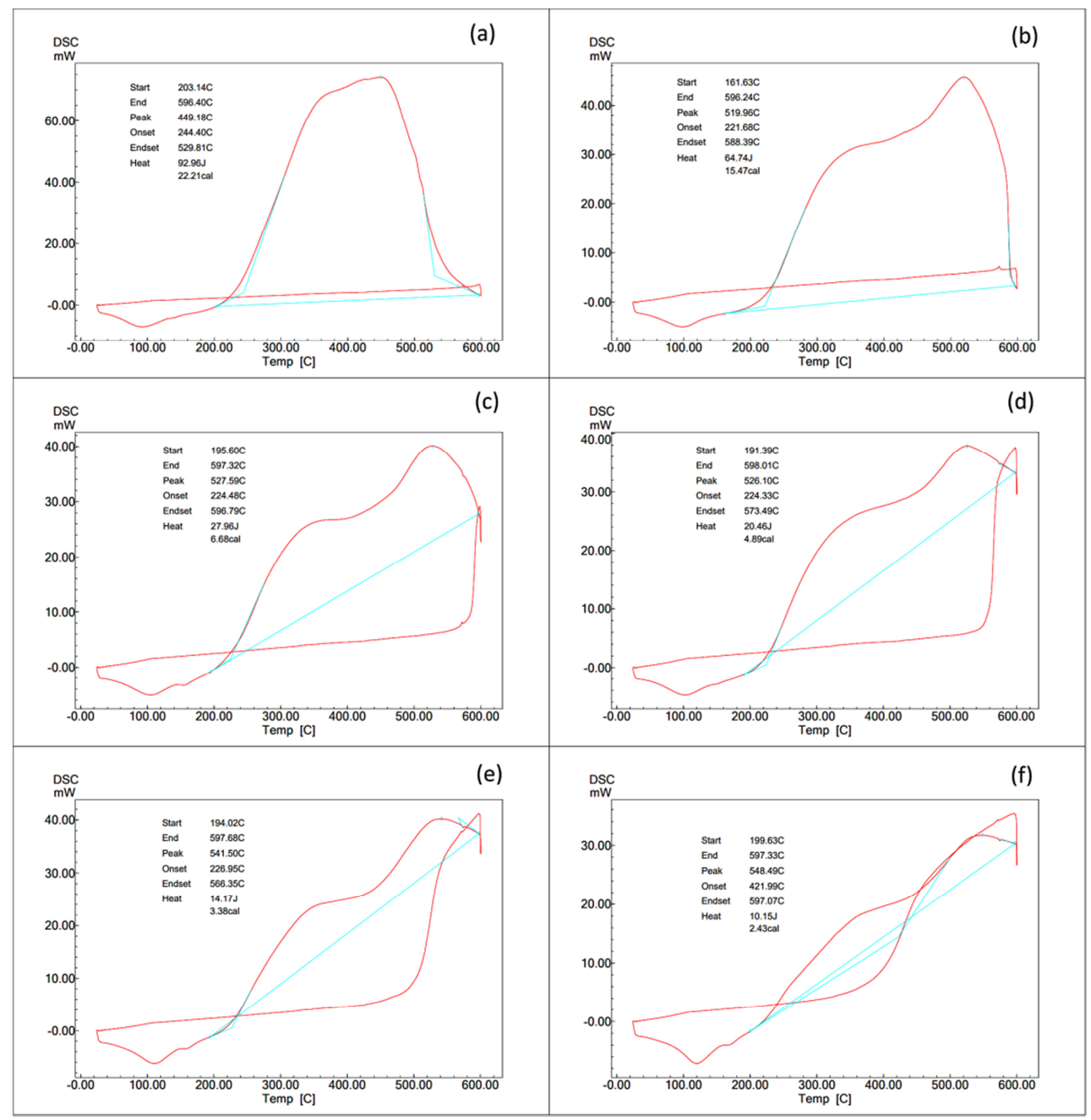

Fig. 1. Thermal effects of MSW compost: (a) - fresh from the drum; (b) - fresh in thermophilic phase; (c) - at the end of the thermophilic phase - the ripening period is up to 1 year; (d) - ripening period 2-3 years; (e) - ripening period 5 years; (f) - ripening period of 7 years. 


\subsection{Biodegradation of PAHs in MSW compost}

Previously, we showed the destruction of PAHs in MSW compost [10]; as part of this study, we incubated model waste containing PAHs in MSW compost for three months. Obtained data (Fig. 2) confirming the previous results - during the incubation, the content of the amount of PAHs decreased by 423 times. These data are in good agreement with other studies.

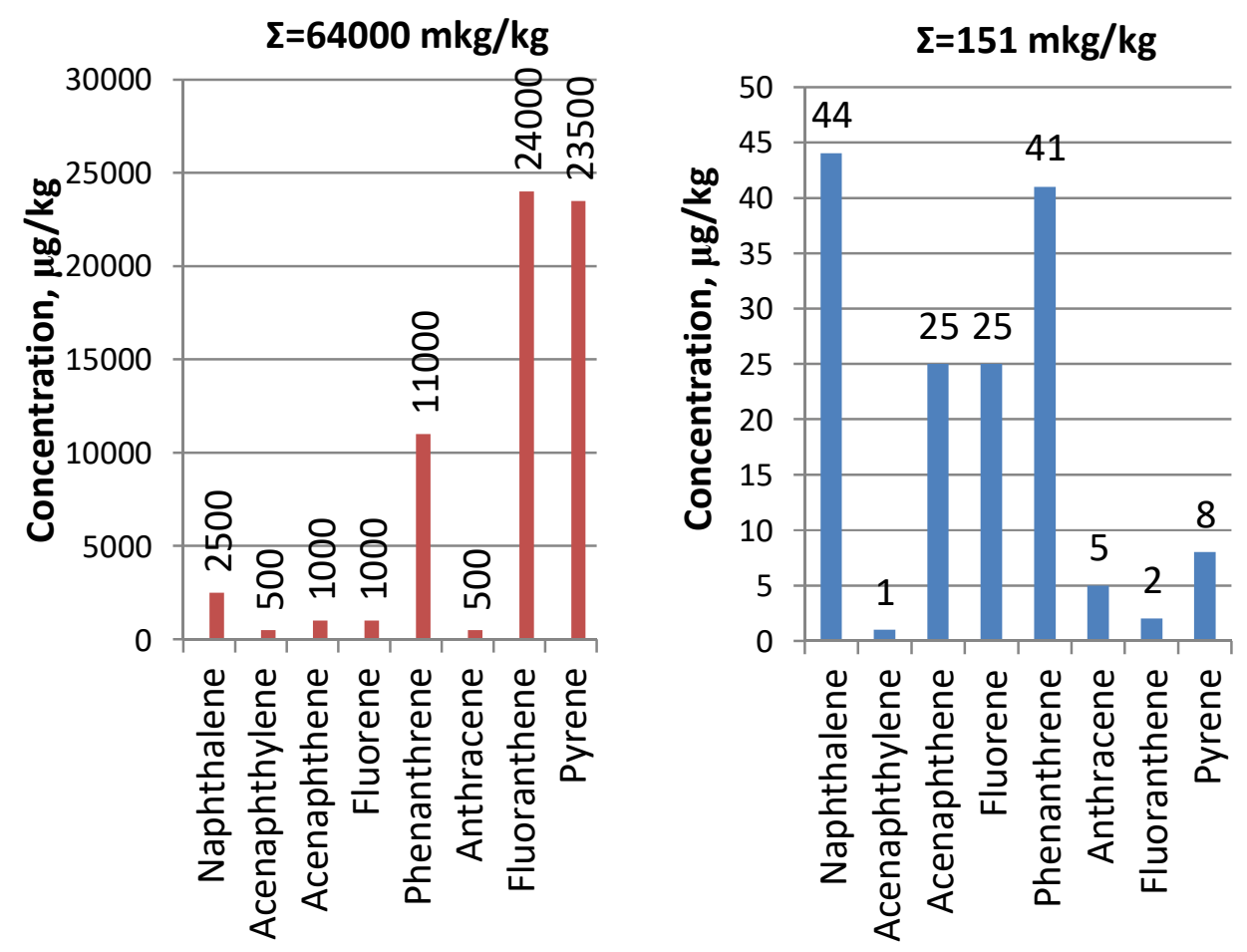

Fig. 2. PAH content in the original compost sample (left) and after compost incubation for 3 months (right).

\subsection{Process recommendations}

Basic information about the technological process of PAH degradation in MSW compost can be represented by the scheme given in Figure 3.

Slightly less than $80 \%$ of the total heat is released by the microbiological processes of ripening compost during three months, when the temperature of the compost is maintained by thermophilic microorganisms due to residual amounts of nutrients in the organic part of the compost. During this period, about $30 \%$ of the compost mass is released in the form of carbon dioxide and water due to the metabolism of aerobic thermophiles.

From the point of view of the economics of the technological process, this means that it does not make sense to keep the substrate on the composting site anymore - it is more profitable to bury it at the landfill, since it lost $30 \%$ of its negative cost (landfill tariff). However, it is important that the compost is accepted as waste of the 4th hazard class, and for this it is necessary that the introduced hazardous waste decompose during this period to the values stipulated by regulatory documents. We have shown that over 3 months the total content of PAHs decreased by 423 times, from this we can conclude that toxic substances should be added to compost in an amount not exceeding 400 -fold norm of pollutant content 
in the 4th waste hazard class. If the cost of receiving toxic waste is high, it makes sense to extend the incubation time, since at a temperature of $38^{\circ} \mathrm{C}$ the destruction of PAHs is better than in thermophilic mode [5], however, in this case, it is necessary to plan the process so that the ripening period in the mesophilic mode accounted for the warm season. In the warm season, compost with ripening periods of more than 1 year can also be used for destruction, since their microbiological characteristics approximately correspond to the soil and contain microorganisms [9], described as PAH destructors [7].

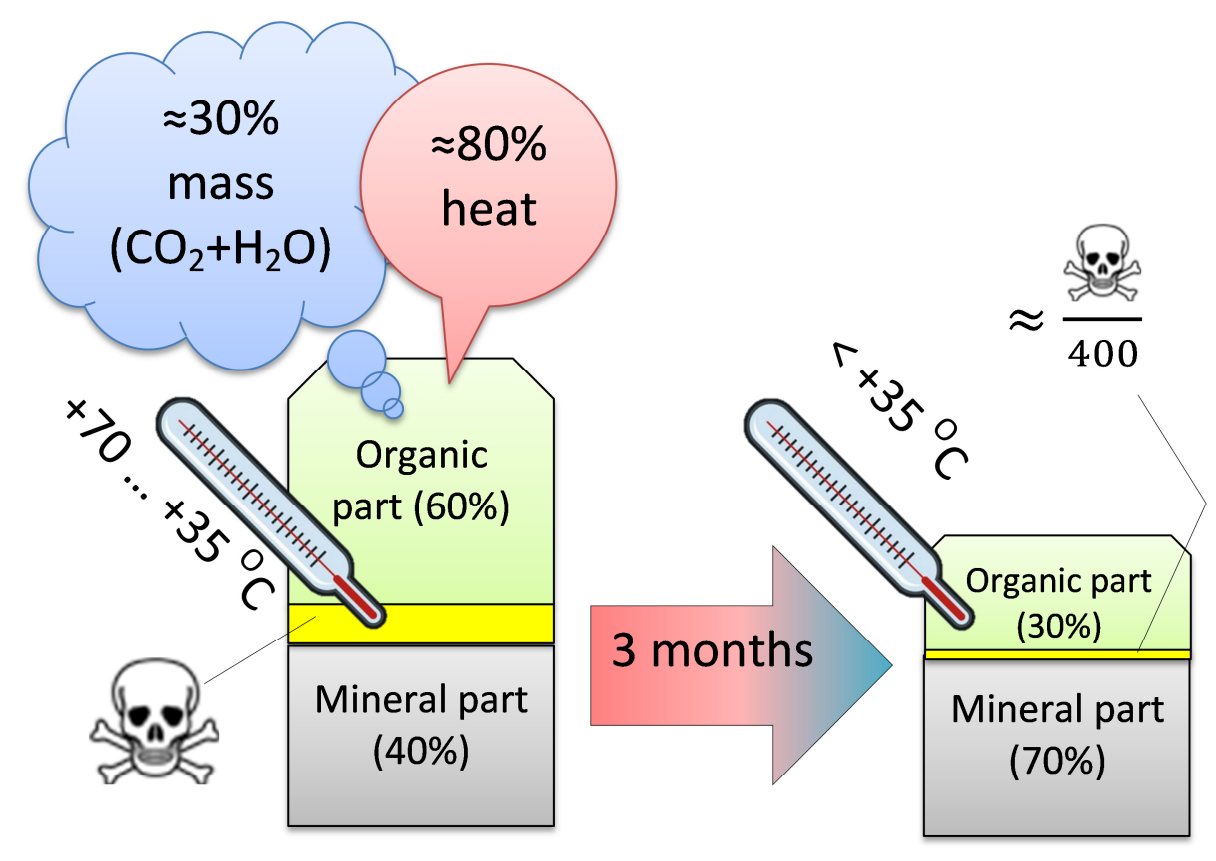

Fig. 3. The main parameters of the process of detoxification of PAHs in MSW compost.

\section{Conclusions}

The chemical composition of industrial compost produced in St. Petersburg does not make it possible to use it as fertilizers and soil in agriculture. From the microbiological point of view, NSW compost is not dangerous, but the content of indicator groups of microorganisms classifies it as contaminated soil. The heat generation of compost during ripening is uneven - the largest share of heat $78.5 \%$ is released in the first year of maturation. In absolute terms, this value is $3250 \mathrm{~kJ} / \mathrm{kg}$ by dry weight. To ensure the process is carried out during a period when the compost temperature is higher than the ambient temperature, toxic substances must be added to the compost in an amount not more than 400 times the pollutant content in waste of the 4th hazard class.

This work was supported by the state mission of the Ministry of Science and Higher Education of the Russian Federation (785.00.X6019).

The equipment of the Engineering Center of the St. Petersburg State Institute of Technology was used in this research. 


\section{References}

1. L. Hua et al. Water, air, and soil pollution 193(1-4), 259-267 (2008).

2. B. Antizar-Ladislao, J. Lopez-Real, A. J. Beck, Environmental pollution 141(3), 459-468 (2006). https://doi.org/10.1016/j.envpol.2005.08.066

3. S. Covino, T. Fabianová, Z. Křesinová, M. Čvančarová, E. Burianová, A. Filipová, T. Cajthaml, Journal of hazardous materials 301, 17-26 (2016). https://doi.org/10.1016/j.jhazmat.2015.08.023

4. H. Feitkenhauer, R. Müller, H. MAuml, Biodegradation 14(6), 367-372 (2003). https://doi.org/10.1023/A:1027357615649

5 Q. Y. Cai, C. H. Mo, Q. T. Wu, Q. Y. Zeng, A. Katsoyiannis, J. F. Ferard, Journal of Hazardous Materials 142(1-2), 535-542 (2007).

6. A. K. Haritash, C. P. Kaushik, Journal of hazardous materials 169(1-3), 1-15 (2009).

7. G. V. Kozlov, A. V. Garabadzhiu, A. V. Ankudinova. Russian chemical journal 55(1), 108-119 (2011).

8. M. J. Kim, H. Lee, Y. S. Choi, G. H. Kim, N. Y. Huh, S. Lee, J. J. Kim, Antonie Van Leeuwenhoek 97(4), 377-387 (2010). https://doi.org/10.1007/s10482-010-9416-6

9. G. V. Kozlov et al., Bulletin of St PbSIT(TU) 41(67), 82-88 (2017).

10. O. V. Ishchenko, Ecology of urban areas 3, 75-79 (2011)

11. I. A. Dudka, S. P. Wasser, I. A. Ellanskaya, Methods of experimental mycology. Reference-book (Kyiv, Naukova Dumka Publishers, 1982)

12. J. G. Cappuccino, N. Sherman, Microbiology: a laboratory manual (San Francisco, Pearson/Benjamin Cummings, 2005) 